\title{
Iranian diplomatic tools in the Face of International Pressure
}

\author{
Emad Mufleh Khalaf Al-khaled \\ The Ministry of Interior of the Hashemite Kingdom of Jordan
}

\section{Abstract}

This study aims to clarify the nature of Iranian diplomacy, its position and its role with regard to managing this file, and the position of some countries in the region and the great powers regarding the Iranian nuclear position.

In order to reach the desired results of the study, the researcher followed the following scientific approaches, namely: The historical research method by tracing the beginnings of the Iranian nuclear file (from 1952 until reaching the final agreement in 2015), the researcher also followed the analytical approach that relies on describing and analyzing the phenomenon and the developments that accompanied the development of the Iranian nuclear file, he also followed the decision-making approach by employing the elements of Iranian political decision-making and the role of Iranian political institutions in taking the appropriate decision regarding the Iranian nuclear file.

Among the results of the study was that Iran, through the (carpet weaving) and (evasive) diplomacy in its nuclear negotiations with the superpowers, was able to achieve its revolutionary goals and build its nuclear project even if it was a peaceful one and avoid reaching the stage of using the military option by the superpowers, this diplomacy has paid off by achieving positive results that serve Iran.

Iran was also able to prove its position and position on the world map and to prove that it is a country with a strategic will to reach its nuclear ambitions, and Iran has been able to resist all threats and temptations in order to continue its nuclear program and forcing the superpowers $(5+1)$ to surrender to her demands at the end. Keywords: Iranian diplomatic tools, International Pressure, Iranian nuclear position, Iranian political decisionmaking

DOI: $10.7176 / \mathrm{JLPG} / 101-20$

Publication date:September 30th 2020

\section{Introduction}

The beginnings of the Iranian nuclear program were in the fifties of the last century during the rule of the Shah, when the United States of America and Western European countries participated in the Iranian nuclear program as part of the "Atom for Peace" program, where the Shah of Iran laid the foundation stone for Iran's nuclear program on March 5 March 1957, following the announcement of the proposed "agreement" for cooperation in research and the peaceful uses of atomic energy "(Al-Sayed, 2015).

In 1967, Iran established the "Tehran Center for Nuclear Research", which was equipped with a nuclear research reactor with a capacity of (5) megawatts, and in 1968 AD, after that Iran signed the Treaty on the NonProliferation of Nuclear Weapons, thus bringing the Iranian nuclear program under the supervision and inspection of IAEA teams The offspring, as Iran's plans at the time were to establish and build 23 nuclear plants by 2000 , with the help of American and European companies (Trenin, 2001).

And with the Iranian Islamic Revolution in 1979, American and Western companies stopped working on nuclear projects, in connection with supplies of highly enriched uranium, which led to the suspension of the Tehran Nuclear Research Center, but Khomeini ordered the dissolution of the Iranian nuclear weapons research center; This is against Islamic law and morals, but it returned in 1981 and allowed small-scale research in the field of nuclear energy, but with the outbreak of the Iran-Iraq war, Khomeini allowed the restart of Iran's nuclear program at Bushehr plant (Trenin, 2001).

Since the beginning of the nineties of the last century, the Russian Federation began providing Iran with experts in Russian nuclear energy, and allegations about an Iranian secret nuclear program had spread at that time. In 1995, Iran signed a contract with Russia to operate the Iranian Bushehr plant. China withdrew from the project to build a uranium conversion plant for Iran. In May 2003, after the US invasion and occupation of Iraq, President Muhammad Khatami had submitted a proposal to conclude a secret deal with the United States of America to offer the Iranian nuclear program with complete transparency, and to stop supporting Hamas and Hezbollah in exchange for security guarantees, and the normalization of relations with the United States of America, but US President George Bush (Jr.) refused to do so (Al-Sayed, 2015).

\section{Significance of the Study}

The importance of this study is that it sheds light on a distinctive tool of achieving the objectives of foreign policy, namely diplomacy, diplomacy that characterized the Iranian Republic, and the stages that the 
Iranian diplomacy went through from revolutionary to realism and from militancy to openness, as well as highlighting the Iranian negotiator who It should be a model for a successful negotiator who has patience, expertise and flexibility. The importance of this study also lies in understanding the methods of Iranian diplomacy, as this importance is based on understanding the developments that occurred in the Iranian nuclear file and Iranian diplomacy, and the impact of these developments on the future of the nuclear file and negotiations with the major countries, and explaining the importance of those developments and Iranian diplomacy and the Iranian-American rapprochement policy, and this is to enrich the information for researchers, scholars, interested persons and research centers, and to find new horizons in scientific research at the level of this important study.

\section{The Study Problem}

The problem of the study is based on studying and analyzing Iran's diplomacy in managing its nuclear file, and how it was able to manufacture a nuclear project and punish it through many forms of sanctions, and despite that it was able with its diplomatic tools to manage its nuclear file with skill and patience and to get out of its isolation that the great countries tried to put in it, and that Iran can build itself an influential position regionally and internationally and impose its conditions on the world's most powerful countries economically and politically.

\section{The Question of the Study}

The study seeks to answer the following question

1. What are the tools of Iranian diplomacy in the face of international pressure?

\section{The limits of the study}

The year (2002) was defined as the beginning of the study and the year (2016) is the end of it to monitor all that is new in Iran's diplomacy in managing its nuclear file with the superpowers $(5+1)$ with which Iran negotiated to find a solution to the crisis of its nuclear file.

\section{The Objectives of the study}

Explaining the nature of Iranian diplomacy, its position, and its role in relation to the Iranian nuclear file.

\section{Previous Studies}

Abdel Hai (2013) conducted a study titled: Smart Power in Foreign Policy. This study deals with the development of Arab-Iranian relations, and a study of Iranian foreign policy tools toward Lebanon (especially), where the study focused on the capabilities and resources of military power in Iran, especially those capabilities related to the Iranian nuclear program, in addition to Iran's continuous attempts to develop its nuclear program, especially since the year 2002, in order to achieve its foreign policy goals and impose its power to obtain its own interests easily and conveniently, and the extent of Iran's ability to transform those resources into effective capabilities in its foreign moves towards Syria, Iraq and Lebanon. The researcher used the analytical method and the decision-making approach to obtain realistic results, and one of the results of the study was that Iran used smart power (evasive) in negotiations and in its relations with neighboring countries and countries of the world, and the researcher recommended to conduct more studies on the topic of its importance.

Maslouh (2013) conducted a study titled "International Dimensions in Nuclear Proliferation Policies". This study aimed to examine the link between political behavior and nuclear proliferation in a way that cannot be separated, and merging several analytical elements from the actors or in terms of procedures to show this interconnection. The study also seeks to clarify that the problems of nuclear proliferation cannot be solved without placing them in their regional environments, In addition to encouraging strategic attention to the problem of nuclear proliferation in the Middle East and the Maghreb, as it is a renewed and dangerous dynamic problem for the region. The study reached important results, including that Iran's interest in nuclear weapons to obtain it did not come from a vacuum, but rather was a result of a global nuclear race and for Israel, which is $1700 \mathrm{~km}$ away from Iran, to obtain a nuclear weapon, which made Iran part of its right. The study called for more studies on The topic, because this issue is very complicated for all decision makers, and it is not possible to predict the status of the Iranian nuclear future in particular, and the international community in general, because it is subject to strategic calculations of a new type.

Robinson, James (2016) conducted a study titled'Iranian Ideology after The Nuclear Deal", This study deals with the Iranian ideology after the Iranian nuclear agreement signed in the month of October 2015 between it and the group of superpowers $(5+1)$, where this study addresses the historical and political dimension of the Iranian nuclear program in terms of the beginnings of the program through the Iranian revolution 1979 and the Iraq-Iran war, To the year 2002 in the beginnings of Iran's development of its nuclear program until 2013 and the initial agreement (or the Agreement of Principles) up to the final 2015 agreement, where the researcher reviews the Iranian diplomacy in which he pursued a policy of evasiveness and deception, it also deals with the nature of the negotiations, the position of President "Barack Obama" on them, and ultimately reaching the American elections, and the position of the new US President "Trump" regarding the Iranian nuclear agreement, which he 
pledged to restore the agreement with Iran for his dissatisfaction with the nature of the agreement and limiting the Iranian role. The researcher used the analytical-descriptive approach to reach the desired results. One of the results of the study was that Iran wants to maintain and develop the agreement and maintain its relations with the United States of America and the West.

Al-Samadi (2014) conducted a study entitled "Iranian nuclear negotiations, Rouhani needs final agreement", as this study examines the possibilities available in the ongoing negotiation process to achieve the final agreement on the Iranian nuclear program, as well as the obstacles facing it and the possibilities of extension of the interim agreement to achieve more time to negotiate points of disagreement, the study argues that it is not possible to reach an agreement that can be described as "exemplary", and concluded The study indicates that the presidential institution in Iran, and within its struggle with other powers, needs to achieve a final agreement, especially that the conditions that were available to achieve it are not repeated, and therefore Rouhani seeks to achieve this in the remaining period, and the researcher assures that the conditions that governed the last period of the relationship between Washington and Tehran, It was exceptional, which may not be available in the future with the electoral benefits in both countries, perhaps the most important of which is the elections of the Assembly of Experts that will be held in Iran next year.

\section{Study methodology}

This study relies on the analytical method, where this approach studies and describes the phenomenon, and here is the Iranian nuclear file, Iranian diplomacy, and Iran's foreign policy as it exists in reality. The analytical approach will focus on understanding and analyzing the nature of Iranian diplomatic tools during its management of its nuclear file and analyzing the stages of negotiations since 2004, up to its negotiations that led to a tentative agreement on its nuclear file in 2013 and then to the final agreement with the $(5+1)$ group in 2015 . Alyan, and Ghoneim, 2011).

\section{Study variables}

Among the most important variables in this study are the following:

- $\quad$ The Independent Variable: Iranian Diplomacy.

- $\quad$ Dependent variable: nuclear file management with superpowers $(5+1)$.

\section{Results of the Study}

The Iranian political system is characterized by the multiplicity of poles that influence the foreign policy system or have the right to express their views or make decision, thus, the diversity of diplomatic tools for Iran, despite the multiplicity of influential forces and the diversity of diplomatic tools However, the position of Supreme Leader is considered one of the important diplomatic tools in Iran in shaping foreign policy by taking major decisions on Iran's foreign policy, and this is confirmed by practical experience, especially dealing with the Iranian nuclear file, as an embodiment of the philosophical framework of the Islamic government based on the idea of governance. In this context, it is important to know that the "guardianship of the jurist" and the philosophical foundations on which it was based lead to the expansion of the limits of the guide's authority and its scope in foreign policy, consequently, he has wide powers in deciding the general features of Iranian foreign policy (AlBatenji, 2013).

This chapter discusses diplomatic tools in the face of international pressure, and will discuss three topics. The first: It will discuss how Iran is searching for a diplomatic solution to end the nuclear file crisis without incurring more losses and international hostility, in the second topic: We discuss Iranian diplomacy, which relies on strategic patience and the so-called "carpet weaving" diplomacy. As for the third topic: We will try to analyze how Iran, with its military arm in the Middle East, was able to put pressure on the $(5+1)$ countries, especially the United States of America, to reach a nuclear agreement and end the crisis.

\section{The first topic}

\section{Iran and the search for a diplomatic solution}

Iran was looking for a diplomatic solution to its nuclear file crisis and to continue its diplomatic endeavors; As Thomas Donilon's national security adviser to President Obama has informed the Israeli Prime Minister Benjamin Netanyahu of an American emergency plan to attack Iran in the event that diplomacy fails to curb Iran's nuclear program, where the United States of America, through its Foreign Minister Hillary Clinton, expressed her concern about the Iranian nuclear program, and she expressed her hope to find a diplomatic solution to the crisis of the Iranian nuclear file, but "Leon Panetta", the former US Defense Secretary, announced that the sanctions did not help in forcing Iran to abandon its nuclear ambition, At a time when Iran was looking for a diplomatic solution to avoid the unabated consequences of the United States of America and its allies (Noland, 2012). 
In order for the study to fulfill its right, the researcher will address in this topic two requirements, as the first requirement will be: Iranian rapprochement with the United States of America, and the second requirement will be entitled: Iranian diplomatic tools to resolve the Iranian nuclear file crisis with the major powers.

\section{The first requirement}

\section{Iranian rapprochement with the United States of America in the era of Rouhani}

Iran, popularly and governmentally, attempted in the early nineties to normalize relations with the United States of America, and perhaps the presence of $70 \%$ of journalists in both countries wishes to hold joint meetings between the two sides, this affects the passion on both sides to discover each other, and the election of Hassan Rouhani ${ }^{1}$ in the summer of 2013 reflected this Iranian societal orientation, Rouhani elaborated it within a political vision called "moderation in foreign policy and dealing with the international community" (Asgard, 2008). This requirement addresses two main axes: the first highlights the Rouhani government's policy of rapprochement with the United States of America, as for the second, it will discuss the tools of Iranian diplomacy under President Hassan Rouhani, those tools that he used in negotiations with the great powers.

First: The Rouhani government's policy of rapprochement with the United States of America.

During the presidency of President Ali Akbar Hashemi Rafsanjani (1989-1997), and under the realistic pragmatic policy, there were attempts to open channels of communication and coordination between the two parties, However, the assassinations of (Mykonos) in Berlin in 1992 AD restored relations between the West and Iran to First square and led to the failure of rapprochement. While the presidency of Muhammad Khatami (19972005) witnessed a new era in Iranian-American cultural relations; Khatami encouraged dealing with IranianAmerican cultural and scientific institutions, such as the Iranian Studies Foundation, And the International Academy of Iranian Studies, the Iran Foundation, and the American Research Center, in the common areas between the two countries, where this center has made great efforts to bring together academics, Iranian elites, and American diplomats on the other hand, However, with the arrival of President Mahmoud Ahmadinejad to the presidency (2005-2013), the Iranian-American rapprochement path has suffered further setbacks (Asgard, 2008). President Hassan Rouhani believes that returning Iran to the international scene and lifting it out of its isolation and economic crises will only be in understanding with the United States of America, which he described as the "Mukhtar of the World" (Rouhani, 2013).

President Rouhani is trying to move within the empty space between the two main currents of the fundamentalist and reformist Iranian revolution, it is a movement that Rouhani defined it as as "Moderation". And in the cultural aspect of this moderation, Rouhani seems close to the proposals of the reformist movement. He is keen to restore these propositions within a conservative speech that does not provoke the fundamentalists, and if we return to the history of man and his positions, we can see this trend. For example, he does not use Western political and intellectual terms and concepts such as democracy, religious reform, and modernity. But you find a discourse full of its contents and meanings, and in this context he expressed his support for the freedom to dress women, the internet, youth, publishing and writers, unlike Ahmadinejad, who relied on preaching the Mahdism to market Iran abroad, Rouhani believes that Iranian culture is able to project the positive political image of Iran in the world.

This is what the Iranian Minister of Culture, Ali Ali Jannati, translated when he said: "Art is the best ambassador for Iran abroad" (Rouhani, Jannati, 2013). Rouhani's foreign policy is betting on the culture tool to redress what the policies of former President Ahmadinejad inflicted on Iran's image at the international level. To accelerate the pace of rapprochement with the West in general and the United States of America in particular, Rouhani's advisor and head of the Cultural Heritage Foundation, "Muhammad Ali," expressed this trend clearly when he argued that cultural diplomacy is sufficient to address the deteriorating relationship between Tehran and the United States of America (Yallouh, 2014).

This clearly means that the government of President Hassan Rouhani will be interested in activating crosscultural diplomacy with the American side, this government may be among the most qualified in the Islamic revolution for this task, this is in view of its members 'acquaintance with, and proximity to, American culture. Whereas, the number of people obtaining a doctorate in his government is more than the number of those who obtain a doctorate in the government of Barack Obama himself (Theatlantic, 2013).

The most prominent example in this framework is the Iranian Foreign Minister, Mohammad Javad Zarif, who is a graduate of the Department of International Relations at the University of Denver, Colorado in 1997, he also held diplomatic positions for his country at the United Nations, and was able to establish a wide network of

\footnotetext{
${ }^{1}$ President Hassan Rouhani: born in 1948, who is the seventh president of Iran, assumed the position of the 29th SecretaryGeneral of the Non-Aligned Movement, Member of the System Diagnostics Complex and member of the Iranian Supreme National Security Council, He was also the chief negotiator of the Iranian nuclear program (Iranian Strategic Studies Center, 2011).
} 
relations among American scientific and political elites throughout his years of scientific or professional residency there since 1976 AD. In the book "Multiple Track Diplomacy", Zarif expressed about this broad understanding of international diplomatic work in which the diplomatic machine uses all possible paths and details in order to guarantee and defend national interests (Zarif and Sadjadpour, 1991).

\section{Second: The tools of Iranian diplomacy during the era of President Hassan Rouhani:}

In order to achieve the goals of Iranian foreign policy, President Rouhani is convinced that he needs to reduce external pressure on Iran, which means reaching a nuclear deal, in an academic article published in January 2013 written by President Rouhani before the presidential campaign, he implicitly compared nuclear negotiations with the United States of America to the resolution that ended the war between Iran and Iraq, and it is likely that the regime's elite view this decision since 1988 as a necessary compromise. But it is temporary regarding the ideals of the Iranian revolution and a way to maintain the regime's survival, and likewise affirmed that the next president should be a director of crises, and he has the authority to negotiate with the world (Abdel Hussein, 2015).

Since President Rouhani's victory in the presidency of the Iranian Republic in 2013, he has followed several forms of diplomacy, including:

1. Popular diplomacy: despite the great activity of various Iranian societies and groups in the American civil and political sphere to this day, the Iranians have not been able to form a unified and coherent pressure group in the US Congress, and there are some sources that talk about the contribution of an Iranian pressure group called "the Iranian-American Political Action Committee" in financing the US elections in 2012; As it ranked third in terms of funding volume after each of the Cuban Lobby, and the Arab Lobby, which occupies the first rank, this group allocated $76 \%$ of its support to the Democratic Party, while $24 \%$ went to the Republicans (Al-Qarawi, 2012).

Since Hassan Rouhani came to power in Iran and during his visit to New York, he has met representatives of the Iranian community in the United States of America; and he promised them to facilitate their communication and movement towards their home country (Iran), and in this context came the initiative of the Iranian and American governments to open a direct air transport line between Tehran and Washington, and revitalizing tourism relations between the two countries, which are steps confirmed by a member of the National Security Committee in the Iranian Parliament, "Ahmad Reza Daghegheb," and a member of the team participating in the visit of President Hassan Rouhani to New York (Daggheeb, 2013).

2. Academic diplomacy: During the era of President Hassan Rouhani, academic relations between Iran and the United States of America were activated. Where the goal behind this is to bring the views between the two countries closer together, as many scholars in Iran have become involved in American universities and research centers, and some of them have made important scientific achievements, In 2011, there were three Iranian scientists out of 94 scientists dedicated to them by President Barack Obama, his annual Science Prize. And there has become an interest in studying the Persian language and Iranian studies, and what distinguishes the Rouhani government is that the number of PhDs from the United States of America in the staff of President Hassan Rouhani is more than those in the staff of the government of President Barack Obama, the thing that President Rouhani exploited to invest and maintain communication, especially in the Iranian nuclear file between Tehran and Washington, and this denies the existence of a non-sectarian divide between the two parties, as some media portrayed it, which indicates a political consensus that President Rouhani later paved for the nuclear negotiations (Yallouh, 2014).

3. Diplomacy of antiquities and literary and national symbols: The Americans are well aware that the Iranian personality is strongly under the influence of its cultural and national elements. Therefore, they seek to use cultural tools of all kinds to communicate with the Iranians, and in their dealings with representatives of the Iranian government, and it is the methodology that the US government called "wrestling diplomacy". This was after the participation of the American wrestling team in a competition in this regard, which was compiled by the Iranian team and This was sought by the Americans to break into the Iranian conscience through the first national sport in Persia (Daggheeb, 2013).

In the context of diplomacy of antiquities and literary and national symbols, The Americans handed an Iranian archeological mug to Iranian President Hassan Rouhani when he visited New York in the fall of 2013. Where the mug was smuggled years ago to America, where the government of the United States of America sought at that time to be a title on its goodwill towards Tehran, In a congratulatory speech on the Iranian Newruz Day on March 21, 2013, President Barack Obama read a poetic part of the Iranian poet Hafez Al-Shirazi. He says in it, meaning, "Show me the tree of friendship whose fruits delight the heart, later in the same year, President Hassan Rouhani, at the end of his first speech to the United Nations General Assembly, New York mentioned a poetic verse of the Iranian poet Ferdowsi, in which he says: "Work hard to do good. You have seen how winter brought spring." This means employing language and literature in the political, diplomatic, and strategic discourse between the United States of America and Iran, this later resulted in the signing of the nuclear agreement, as these signs were close relations between the two countries during the era of President Hassan Rouhani (Iranian Foreign 
Ministry, 2013).

In my opinion, these data confirm that the Iranian nuclear agreement with the United States of America did not come from a vacuum but rather had preludes, as that diplomacy (popular, academic, literary and nationalistic symbols and symbols), that Iranian President Rouhani followed provided a high rate of positive cultural and political opportunities and capabilities between Iran and Washington, what facilitates any efforts and rapprochement steps between the two countries in the future, i.e. after 2013, and this indicates the pragmatic style adopted by President Hassan Rouhani in his communication with the United States in order to obtain concessions regarding the Iranian nuclear file.

\section{The Second Requirement}

Iranian diplomatic tools to solve the nuclear crisis

First: The Iranian nuclear file during the era of President Rouhani: After the Iranian President assumed his duties as President of Iran, he worked to transfer the nuclear negotiation file from the Iranian Supreme National Security Council to the Ministry of Foreign Affairs. In order for diplomatic negotiation to become the share of Foreign Minister Muhammad Javad Zarif, this détente reflected on the positive global attitudes that were issued after President Rouhani's victory, such as the statement by Catherine Ashton, the European Union's foreign affairs chief, that Rouhani's victory allowed a rapid diplomatic solution to the Iranian nuclear file, where Ashton expressed its intention to work with the Rouhani government to quickly reach a diplomatic solution to the nuclear issue (Abdul Hussein, 2015).

It is noticeable that the method of dealing with the Iranian nuclear file has changed during the era of President Rouhani, and that a new mechanism has been adopted to transfer the nuclear file from the Supreme Council for National Security (Shura Council) to the Ministry of Foreign Affairs, which allows the Presidency foundation to cooperate with Foreign Minister Muhammad Javad Zarif and the opportunity to be more free, and less central to dealing with the negotiation process, and among the reasons that made President Rouhani change the way to negotiate the Iranian nuclear file is to end Iran's international isolation, and reviving the Iranian economy if it agreed to give more guarantees on the peace of Iran's nuclear program (Arjomand, 2013; Al-Atoum, 2015).

There are other goals for both the American and Iranian sides because of the diplomatic approach in resolving the Iranian nuclear file, and by looking at the motives and goals of each side, we find that the Americans wanted, thus, to cut off the path of forming Russian alliances in the Middle East that are opposed to the policy of the United States of America.

The American administration also wanted to enter the nuclear file strongly with Iran, through solid and comprehensive understandings that enable Iran to make strong concessions if it feels that the shift in relations is working in its favor, and the American administration wanted to support the moderate current of the reformists, headed by President "Hassan Rouhani" at the expense of the hard line against the United States of America, the US administration also considered Iran's successes in forming real influence and participation in its interests, allies, capabilities and expansion in the region from Iraq to Yemen to Syria, Lebanon and Gaza, it considered this a strategic point of weight for Iranian diplomacy and politics, and it has become a phenomenon that is difficult to overcome. It has also become a regional superpower phenomenon, which is constantly expanding and competing strongly with the power of Israel and the United States, which caused the United States of America to consider understandings with Iran, as this may constitute an input and a catalyst for solving the problems of Syria and Palestine through understanding with Iran, where the United States of America delivered messages of understanding with Iran under the new Iranian President, Hassan Rouhani, and in light of the understandings about the destruction of the Syrian chemical weapons (Al-Hamd, 2013).

And after the election of Hassan Rouhani, the American administration was aware that the Iranian president, "Hassan Rouhani", was able more than any other Iranian president since 1979 to fulfill a nuclear deal with the West. And with the support of the guide, "Ali Khamenei", he is able to restrain the forces of the insurgency in the structure of the Iranian authority, as it was not available to the real presidents, "Rafsanjani and Khatami." Also, reforming what Ahmadinejad has corrupted with his foreign diplomatic policy that led to the collapse of the Iranian economy (Arjomand, 2013).

After Rouhani's victory in the 2013 elections, the United States of America announced that it was ready to cooperate directly with Tehran on its nuclear file, and this came in the words of the White House chief of staff, and the US administration announced that it was ready to cooperate directly with Tehran on its nuclear file in order to find a diplomatic solution, as a minister commented. French Foreign Minister "Laurent Fabius", that his country "is ready to work with him, especially on the nuclear file, and Iran's engagement in Syria," but the Israeli entity, in the words of the foreign minister, stated: "The decision of the Iranian nuclear program so far is in the hands of the Supreme Leader" Ali Khamenei "It is not in the hands of the Iranian President and Iran must respond to the demands of the international community to stop its nuclear program" (Abdul-Hussein, 2015). 


\section{The second topic}

Iran and the diplomacy of (carpet weaving)

The carpet industry is one of the oldest and most famous handicrafts in Iran, and carpet weaving needs patience, dream, efficiency and high skill, and Iranian carpet weaving policy and diplomacy has been borrowed from it, because it needs patience and high efficiency and needs more than one stage. What is meant here is the process of external political decision-making In the Islamic Republic of Iran, through the interaction of several official institutions as well as several internal and external factors, and among the official institutions responsible for decision-making in Iranian foreign policy: the constitution, the leader or guide, the Islamic Shura Council (the Constitution Industry Council), the government or the executive authority (Bezen, 2000).

This topic addresses the discussion of two important requirements, as the first demand will be entitled, Iranian political decision-making institutions, while the second will address: the role of diplomacy (carpet weaving) in the Iranian nuclear agreement, because this diplomacy needs patience, sophistication and cunning.

\section{The first requirement}

Iranian political decision-making institutions

The decision-making process in the foreign policy of the Iranian Republic is the interaction of several official institutions, as well as several internal and external factors, where foreign policy is distinguished, in all political systems, that it has specific and limited channels for decision-making, in other words that only a few officials and competent sources are concerned. Those who have the ability to draw foreign policy and make a decision on it, but in Iran, the decision-making process passes through several official channels, and there are unofficial sources entitled to express its opinion on foreign policy decision-making and take it according to documents and documents, especially the Iranian constitution, the official source of decision-making and decision (Muhammad, 2005).

\section{The second requirement}

The role of diplomacy (carpet weaving) in the Iranian nuclear deal

President Hassan Rouhani presented his views of the decision-making process (carpet weaving) in his memoirs that he published before his election at the presidential presidency, which is located under the title (Tadbir Wamid State), comparing the situation in which the beginnings of the Islamic revolution were followed (19792013), according to the division Next: (Abdul Hussain, 2015):

First: President Rouhani's perceptions of diplomatic decision-making and carpet weaving

1- In the early years of the Islamic Revolution, Rouhani sees that there are several centers for decisionmaking and decision-making in the country, such as the Leadership Foundation and the House of the Imam and the Shura of the Revolution, as well as the interim government and the Islamic Republican Party, although the House of the Imam and the Islamic Republican Party, have no An official site in the state's structure, but they are considered to be one of the main and original power centers in the state, and it is mentioned that many decisions and decision-making processes were taking place in these two centers at that time, with no constitution, and the Council as well with the weak ability of the interim government in light of the atmosphere of beginnings The revolution, and most decisions were taken by the Shura Council.

2- Rouhani believes that the election of the President of the Republic, the formation of the Islamic Shura Council, the appointment of the government i.e. the legislative and executive powers, and the discussion of these two institutions of the Shura Council committees on very important issues.

\section{Second: Muhammad Jawad Zarif, the model of realism and diplomacy (carpet weaving)}

Iranian Foreign Minister Mohammad Javad Zarif had confirmed that the Geneva Agreement represented a first step towards a comprehensive solution to the Iranian nuclear program, and the Foreign Minister, who is considered a model for the Iranian realist school, stressed that Iran continues to enrich uranium and that new measures will not be imposed on Iran in return, gradually reducing the risk Zarif focused on Iran's right to enrich in accordance with the Nuclear Non-Proliferation Treaty and said in this regard, "We entered the agreement in good faith and the other party must prove this in return" (Washington Post, 2015; Abdul Hussain, 2015).

From the first rounds in Paris in 2003 to the last lines of Vienna in 2015, the slogan of the peaceful nuclear solution was drawn on the drafts of negotiations and their ovaries with the needle of the skillful Iranian carpet weaver. Or the concept of flexible diplomacy, which was ordered by Supreme Leader Khamenei, where the Vienna Agreement came after years of anticipation and delay imposed by the difficulty of the negotiations, but eventually resulted in the signing of a good agreement for all, while Muhammad Javad Zarif described this agreement as historic and good for both parties (Ismail, 2015). 


\section{The third topic}

Iranian diplomacy (the military arm) in the Middle East

Tehran has assumed since the beginning of the Arab Spring revolutions, especially since the month of April 2015 through the Iranian Revolutionary Guard forces directly command six armies, and it manages four wars in four Middle Eastern countries: Iraq, Yemen, Syria and Lebanon, where the volume of investments and monthly expenditures on those armies and wars Nearly half a billion dollars, and sometimes more, and in other words, Iran spends 6-8 billion dollars annually on the wars involved, using those wars as a diplomacy called (the military arm) to pressure Washington over its Iranian nuclear file (Kia, 2015).

\section{The first requirement}

The role of diplomacy of the military arm in (Syria and Lebanon)

The role of the Islamic Republic of Iran in the Middle East can no longer be ignored because of the emptiness and confusion that deepens in it. The Middle East region is witnessing a new historical acceleration, twenty years after the collapse of the Soviet Communist bloc, which opened the region to the multiple capitalist Western interventions that the United States and its allies have fought, After the Arab Spring and the Arab popular uprisings since 2011; Several factors led to Iranian interference in Syria and Lebanon in particular due to the neoliberal attack in recent decades, the corruption of the ruling elites, the nature of tyranny specific to the countries of the region and imperialist politics, and the desire to obtain concessions in its nuclear file, using diplomacy (the military arm to achieve its goals) (Kia, 2015).

First: Iranian interference in Syria:

The shift in US-Iranian relations in the event of the completion of its nuclear political and strategic path constitutes an important shift in the balance of regional powers, as Iran is advancing to be the first Middle Eastern country alongside Israel to possess nuclear technology in addition to reaching a system of international understandings, especially in light of the decline in the Turkish regional role Also, the transformation could weaken the relative weight of the Gulf states in the American strategy, and encourage Iran to participate in the peace process between Israel, the Arabs and the Palestinians, as this transformation represents an important blow to the Arab Spring, especially in light of tensions and chaos in some Arab countries, not to mention the impact of that transformation On the Syrian and Yemeni issue and its implications in Iraq, and its positive impact on the Iranian nuclear file (Al-Hamd, 2013).

Iran views the ongoing war in Syria and its support for the Assad regime on the basis that it is a proxy war against the United States of America and Israel as well as Western countries, as Iran considers itself a "axis of resistance" against the West and this is why they allied with the Syrian Alawite regime and the Lebanese Hezbollah, as well as in the Gaza Strip from The Hamas Road, which is a leverage for Israel (Manfreds, 2014).

\section{Second: the Iranian alliance with the Lebanese Hezbollah}

There is no doubt that the presence of the Islamic State "ISIS" in Iraq and Syria threatened Iranian influence inside both countries. The Islamic state, with its Sunni doctrine, takes an Shi'ite Iran as an enemy that works to reduce its influence, and this has appeared in Iraq and still is, after the Islamic State's defeat of the Iraqi army, it sought Iran supported the Shiite militias and the Sadr forces in its war against ISIS, and at the same time, the support of the Syrian regime represented yet another war front against the Islamic State in Syria (Akbarzadeh, 2014).

And in order for Tehran to achieve its strategic goals, in its entirety, it had to provide that support through political, economic and military tools, and perhaps the political tools are limited to supporting a peaceful solution to the Syrian crisis without overthrowing Bashar al-Assad as well as putting the Syrian crisis on the table of its nuclear project negotiations, while the economic is financial support for the regime In addition to providing oil as one of the important resources among the economic sanctions imposed on Syria, and at the indirect military field level, Hezbollah's role as one of the important and main tools in supporting the Syrian regime is highlighted. As one of the actors pressing on the Lebanese internal affairs to achieve its goals, Hezbollah's cooperation with the Syrian regime in the Syrian crisis is accompanied by clear encouragement and support by Tehran, and this cooperation was made clear by the director of the Stein Program for Intelligence and Counter-Terrorism at the Washington Institute, Matthew Levitt, where He affirmed that Hezbollah has "closely aligned" itself with the Iranian Quds Force while fighting alongside the Assad regime (Al-Samadi, 2015).

\section{The Second Requirement}

The Role of Diplomacy of the Military Arm in (Yemen)

The Iranian regime, with the support of the Supreme Leader, allied with forces in Yemen seeking to destabilize the central government in 2001, and Saudi Arabia was then supporting former President Ali Abdullah 
Saleh, in order to preserve its interests in Yemen, and the Houthis were spread along the Yemeni-Saudi border, so therefore Riyadh is concerned about this extension, and since in November 2009 the Houthis took control of a portion of the kingdom's lands, and clashes took place between the two sides that resulted in huge losses in the ranks of the Saudi army, where more than (110) Saudi soldiers were killed in These clashes, and the Houthis brought down a Saudi Apache plane, and Saudi Arabia has accused both Iran and Lebanese Hezbollah that senior officials of the Iranian Revolutionary Army Corps and the Lebanese Hezbollah have met with Houthi rebels to coordinate operations against Saudi Arabia, and Saudi Arabia has confirmed Iran's involvement in fighting in Yemen and support for the Houthis (Schenker, 2010).

\section{Conclusion and results}

Nuclear weapons have caused a profound reversal of strategy, since the use of the nuclear bomb against Japan in World War II, the major powers have been convinced that they will not be strong without acquiring a nuclear weapon, the latter has become a central criterion for the interpretation and analysis of power, and countries have entered a strategic race based on the acquisition of strategic nuclear weapons. At the same time, the countries that enjoyed this superiority, especially the United States of America, sought to make the nuclear weapon a controlling weapon and guarantee their superiority. The start of this was during the famous Bernar Barouch project in 1946, which was based on the formation of an International nuclear control authority. Accordingly, and due to Iran's position in the Middle East region, it sought to acquire a nuclear weapon, and the beginnings of that endeavor were in 1953, and the year 2003 is considered the beginning of the serious development of its nuclear program, and it has gone through several stages.

Today, the Iranian nuclear problem lies within one of the global strategic problems, especially in a volatile region. Indeed, this problem does not come from Iran's possession of nuclear weapons alone, rather, the effects of this on the American leadership and its allies and partners in the region, especially Israel and Saudi Arabia, except that Iran put its program under international control after the United States imposed an economic blockade on it. This, in turn, led to negotiations with the Great Powers $(5+1)$ permanent members of the UN Security Council plus Germany. The negotiations resulted in a tentative agreement on November 24, 2013, then those countries followed the discussions and negotiations in which Iran used (carpet weaving) diplomacy that requires patience, it also used dodge diplomacy and tricks until a final nuclear agreement was signed with Iran on July 14, 2015. Under which Iran obtained the release of its frozen assets, the dismantling of the economic blockade and the improvement of its relations with Western countries and the United States of America, However, the victory of "Donald Trump" in the 2016 US elections may be an obstacle to continuing the nuclear agreement. Whereas, Trump threatened to restore or tear the agreement, because Iran is the only country to win the benefits of that agreement, according to his beliefs.

\section{References}

Abdel-Hussein, Y. (2015). Iranian Foreign Policy (The Future of Politics Under President Hassan Rouhani), 1st Edition, Publications for Distribution and Publishing, Beirut.

Al-Atoum, N. (2015). The Iranian nuclear train runs without brakes towards the militarization station, Umayya Center for Research and Strategic Studies, Istanbul.

Al-Atoum, N. (2015). Iran (After the Nuclear Deal and Relations with Washington), Iranian Studies Unit, Umayya Center for Research and Strategic Studies, Istanbul, Turkey.

AkbarZadeh, S. (2014). "What Ayatollahs Are Still Supporting Assad", retrieved from: http://www.noonpost.net/ontend/9/2014

Al-Hamad, J. (2013). "Options for the Transformation in American-Iranian Relations and Their Repercussions," Journal of Middle Eastern Studies, No. 65.

Al-Sayed, A. (2015). The Iranian nuclear program was started by the United States of America and concluded with a historic agreement, 2015, see website: www.sasapost.com/15/15

Al-Smadi, F. (2015). Why does the economically impoverished Iran continue to support its allies ?, Al-Jazeera Center for Studies and Research, Doha, Qatar, 2015.

Alyan, R. \& Ghoneim, O. (2013). Scientific Research Methods (Theoretical Bases and Practical Application), 1st Floor, Safaa House for Publishing and Distribution, Amman.

Ismail, M. (2010). from the Shah to Ahmadinejad .... Iran, where to ?, The Arab Center for Publishing and Distribution, Egypt.

Kia, B. (2015). Islamic Republic of Iran and Emptiness in the Middle East, The Permanent Revolution Magazine, Paris, No. 5.

Manfred, P. (2014). Why Iran supports the Syrian Regime, retrieved from: http://middleast.about.com/od/Iran/tp/why-Iran-supports-the-syrain-Regime-htm

Maslouh, K. (2013). International Dimensions in Nuclear Proliferation Policies, Journal of Middle Eastern Studies, No. 63, Amman, Jordan. 
Muhammad K. (2005). Decision Making in the Foreign Policy of the Islamic Republic of Iran, World of Nations Amman, Jordan.

Schenker, D. (2010). Behind the Houthis, The Washington Institute for Near East Policy, Washington, USA.

Trenin, D. (2001). Dimitriles relations russo-americaines a lepreuve de la prpliferation, polittique etrangere, paris Yallouh, R. (2014). Cultural Background of Iranian-American Rapprochement, Arab Center for Research and Policy Studies Doha, Qatar, Spring 2014. 